\begin{tabular}{|c|c|}
\hline Title & $\begin{array}{l}\text { Molecular and cytological evidences denied the immediate hy brid hy pothesis for Saxifraga yuparensis ( sect. } \\
\text { Bronchiales, Saxifragaceae) endemic to Mt. Y ubari in Hokkaido, northern Japan }\end{array}$ \\
\hline Author(s) & $\begin{array}{l}\text { Tamura, Say a; Fukuda, Tomoko; Pimenova, Elena A.; Petrunenko, Ekaterina A .; Krestov, Pavel V.; Bondarchuk, } \\
\text { Svetlana N.; Cherny agina, Olga A.; Suyama, Y oshihisa; T sunamoto, Y oshihiro; M Matsuo, A yumu; Tsuboi, Hay ato; } \\
\text { Takahashi, Hideki; Sato, Ken; Nishikawa, Y oko; Shimamura, T akashi; Fuji ita, Hiroko; Nakamura, Koh }\end{array}$ \\
\hline Citation & $\begin{array}{l}\text { Phy totaxa, 373(1), } 53.70 \\
\text { https://doi.org/10.11646/phytotaxa.373.1.2 }\end{array}$ \\
\hline Issue Date & $2018-10-23$ \\
\hline Doc URL & http:/hdl.handle.net/2115/2152 \\
\hline Rights(URL) & http://reativecommons.org/icenses/by $\beta .0$ \\
\hline Type & article \\
\hline File Information & 32722-143779-1-PB.pdf \\
\hline
\end{tabular}

Instructions for use 


\title{
Article
}

https://doi.org/10.11646/phytotaxa.373.1.2

\section{Molecular and cytological evidences denied the immediate-hybrid hypothesis for Saxifraga yuparensis (sect. Bronchiales, Saxifragaceae) endemic to Mt. Yubari in Hokkaido, northern Japan}

\author{
SAYA TAMURA ${ }^{1,2}$, TOMOKO FUKUDA $^{3}$, ELENA A. PIMENOVA ${ }^{4}$, EKATERINA A. PETRUNENKO ${ }^{4}$, PAVEL \\ V. KRESTOV ${ }^{4}$, SVETLANA N. BONDARCHUK ${ }^{5}$, OLGA A. CHERNYAGINA ${ }^{6}$, YOSHIHISA SUYAMA ${ }^{7}$, \\ YOSHIHIRO TSUNAMOTO ${ }^{7}$, AYUMU MATSUO ${ }^{7}$, HAYATO TSUBOI ${ }^{8}$, HIDEKI TAKAHASHI ${ }^{9}$, KEN SATO ${ }^{9}$, \\ YOKO NISHIKAWA ${ }^{10}$, TAKASHI SHIMAMURA ${ }^{10}$, HIROKO FUJITA $^{11} \&$ KOH NAKAMURA ${ }^{11}$ \\ ${ }^{I}$ Division of Environmental Resources, Graduate School of Agriculture, Hokkaido University, Sapporo 060-8589, Japan \\ ${ }^{2}$ Japan Wildlife Research Center, Tokyo 130-8606, Japan \\ ${ }^{3}$ College of Liberal Arts and Sciences, Mie University, Tsu 514-8507, Japan \\ ${ }^{4}$ Botanical Garden-Institute, Far Eastern Branch of the Russian Academy of Sciences, Makovskii Str. 142, Vladivostok, 690024, Russia \\ ${ }^{5}$ Sikhote-Alin State Nature Biosphere Reserve, Ministry of Nature Resources and Environment, Terney 692150, Russia \\ ${ }^{6}$ Kamchatka Branch of Pacific Institute of Geography, Far Eastern Branch of the Russian Academy of Sciences, Petropavlovsk- \\ Kamchatsky 683000, Russia \\ ${ }^{7}$ Field Science Center, Graduate School of Agricultural Science, Tohoku University, Naruko-onsen, Osaki 989-6711, Miyagi, Japan \\ ${ }^{8}$ Hakuba-Goryu Alpine Botanical Garden, Hakuba 399-9211, Japan \\ ${ }^{9}$ The Hokkaido University Museum, Hokkaido University, Sapporo 060-0810, Japan \\ ${ }^{10}$ Institute of Environmental Sciences, Hokkaido Research Organization, Sapporo 060-0819, Japan \\ ${ }^{11}$ Botanic Garden, Field Science Center for Northern Biosphere, Hokkaido University, Sapporo 060-0003, Japan, \\ kohnakamur@gmail.com
}

\begin{abstract}
An alpine plant Saxifraga yuparensis is endemic to a scree consisting of greenschist of Mt. Yubari in Hokkaido, Japan and it has been proposed as an immediate hybrid derived from two species of the same section Bronchiales based on morphological intermediacy: namely $S$. nishidae, a diploid species endemic to a nearby cliff composed of greenschist and tetraploid S. rebunshirensis comparatively broadly distributed in Japan and Russian Far East. Saxifraga yuparensis is red-listed and it is crucial for conservation planning to clarify whether this is an immediate hybrid and lacks a unique gene pool. The immediate-hybrid hypothesis was tested by molecular and cytological data. In nuclear ribosomal and chloroplast DNA trees based on maximum parsimony and Bayesian criteria, S. yuparensis and S. rebunshirensis formed a clade with several other congeners while $S$. nishidae formed another distinct clade. Genome-wide SNP data clearly separated these three species in principal coordinate space, placing $S$. yuparensis not in-between of S. rebunshirensis and S. nishidae. Chromosome observation indicated that $S$. yuparensis is tetraploid, not triploid directly derived from diploid-tetraploid crossing. Additionally, observation of herbarium specimens revealed that leaf apex shape of S. yuparensis fell within the variation of S. rebunshirensis. These results indicate that $S$. yuparensis is not an immediate hybrid of $S$. rebunshirensis and $S$. nishidae but a distinct lineage and an extremely narrow endemic species, that deserves for intensive conservation.
\end{abstract}

Keywords: Alpine plant, Bronchiales, diabasic plant, genome-wide SNP, hybrid, Japan, MIG-seq, Russia, Saxifraga, tetraploid

\section{Introduction}

The genus Saxifraga L. (1753: 398) (Saxifragaceae, e.g., Soltis et al. 2001) encompasses more than 440 species and is composed of at least 13 sections and nine subsections (Tkach et al. 2015). One of the Saxifraga sections, sect. Bronchiales DeChaine E.G. (2014: 27) was subdivided from sect. Trachyphyllum Koch W.D.J. (1836: 270) based on molecular phylogenetic analyses (DeChaine et al. 2013, DeChaine 2014). This section has approximately 20 species (DeChaine et al. 2013, DeChaine 2014) mostly in northern high latitudes, and among them, three species are distributed in Hokkaido, northern Japan: S. yuparensis Nosaka (1974: 149), S. rebunshirensis Sipliv. (1971: 155), and S. nishidae 

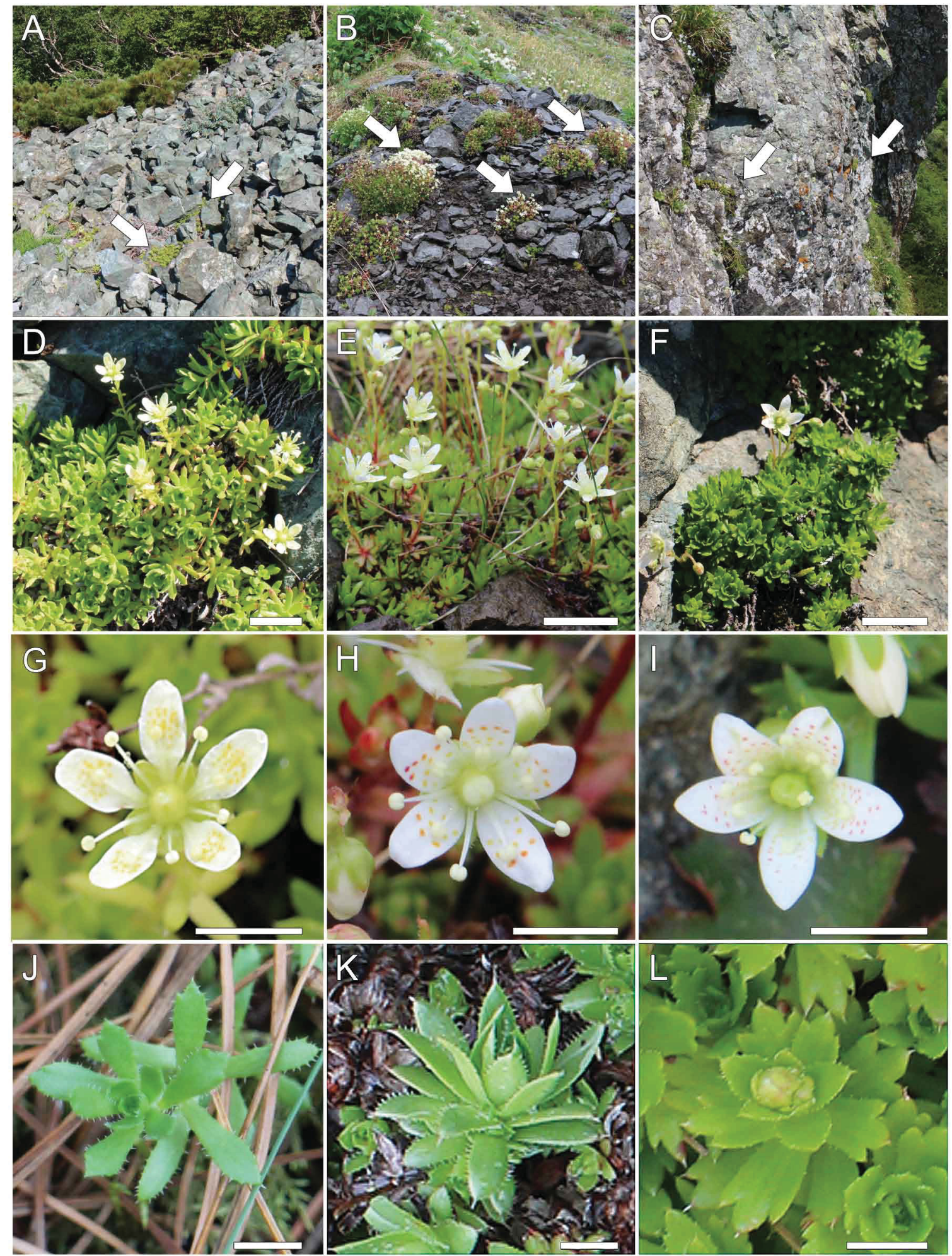

FIGURE 1. Saxifraga yuparensis (A, D \& J 26 July 2016, G 19 July 2017, Gama-iwa at Mt. Yubari), S. rebunshirensis (B, E, H \& K, 10 June 2016, Rebun Island), and S. nishidae (C, F, I \& L, 26 July 2016, Gama-iwa at Mt. Yubari). A, B \& C Habitat. D, E \& F Habit. G, H \& I Spots on petal. J, K \& L Leaf. Scale bars are $1 \mathrm{~cm}$ for D-F and $5 \mathrm{~mm}$ for G-L. The figure is available in color online.

Miyabe \& Kudô (1917: 170) (Fig. 1 \& 2). Saxifraga rebunshirensis is broadly distributed in Japan (Hokkaido and high mountains in Honshu) and Russian Far East (Sakhalin and the Kuril Islands), while S. yuparensis is endemic to a scree consisting of greenschist at Mt. Yubari in Hokkaido and S. nishidae is endemic to a cliff composed of greenschist at Mt. Yubari and a cliff of schalstein at Mt. Ashibetsu, Hokkaido (Shimizu 1983, Charkevicz 1989, Sato 2007, Nakagawa \& Sato 2015). Mountains composed of diabasic rocks (including greenschist, shalestein, etc.) are known to house plants 
adapted to infertile soils and fragile geological features, as is the case in several endemics in Mt. Yubari (Watanabe 1971, Nosaka 1974). Diabasic plants are typically narrow endemics and grow on unstable soils (Watanabe 1971), and thereby include many endangered species. The number of individuals and patches of $S$. yuparensis are decreasing due to collapse of rocks and collection for horticultural purposes, and it is designated as an endangered species: CR (critically endangered) at the national level (Ministry of the environment of Japan 2017) and En (Endangered) at the provincial level (Hokkaido 2001).

The diagnostic characters of these three species are the color of petal spots, presence/absence of a conspicuous claw of petal base, and the shape of leaf apex. Saxifraga yuparensis has yellow petal spots, petal claws, and slightly tricuspidate leaves; S. rebunshirensis has yellow and red (irregularly only yellow) petal spots, claw-less petals, and cuspidate leaves; S. nishidae has yellow and red petal spots, claw-less petals, and tricuspidate leaves (Miyabe \& Kudô 1917, Hara 1952, Murata 1961, Nosaka 1974, Nosaka 1980, Shimizu 1983, Ohba 1999, Nakagawa \& Sato 2015). However, several authors considered that S. yuparensis is an immediate hybrid derived from crossing between S. rebunshirensis and S. nishidae based on morphological intermediacy in the shape of leaf apex (Toyokuni 1988, Nishikawa et al.1992, Iwatsuki \& Kato 1994, Umezawa 2004, Shimizu et al. 2014, Takahashi 2015a). Additionally, seeds of S. yuparensis rarely germinate (Shimizu 1983) and this suggests that the species is an infertile triploid hybrid, because $S$. nishidae is diploid $(2 \mathrm{n}=26$, Funamoto \& Nakamura 1993) while $S$. rebunshirensis is tetraploid $(2 \mathrm{n}=$ 48 using samples with no locality information, Sakai, 1935; $2 \mathrm{n}=50$ with samples from Nagano of central Japan, Funamoto \& Nakamura 1990), although the chromosome number of S. yuparensis has not been reported. The hybridorigin hypothesis, however, has not been tested by molecular analyses. On the other hand, S. yuparensis is sometimes treated as a synonym or variety of S. rebunshirensis (Shimizu 1983, DeChaine 2014, Takahashi 2015a, Okuyama 2016; note the last one is the latest Japanese flora). For planning the conservation of S. yuparensis, it is crucial to clarify whether this is an immediate hybrid and lacks a unique gene pool. In a preceding molecular phylogenetic study of Saxifraga, the species relationships were partially revealed, but the relationship among the three species remained unclear (DeChaine et al. 2013). The aim of this study is to elucidate the species relationships and test the immediate-hybridity of $S$. yuparensis using molecular analyses and cytological observation. In molecular analyses, DNA sequencing and genome-wide single nucleotide polymorphism (SNP) detection were employed. Collaterally, the diagnostic character of leaf apex shape was investigated using specimens of the three species to reevaluate the morphological intermediacy of $S$. yuparensis.
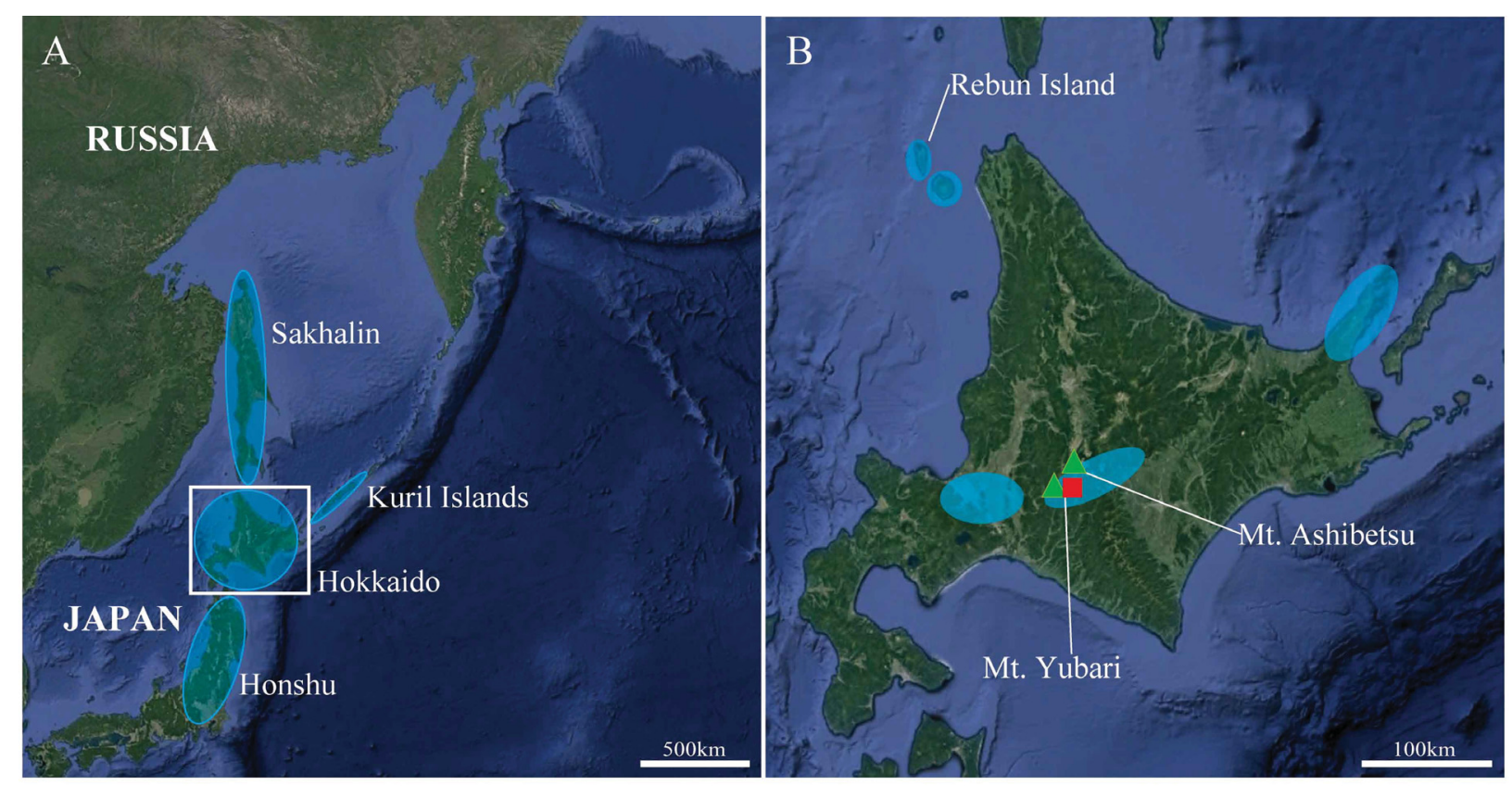

FIGURE 2. Maps of East Asia (A) showing the species range of Saxifraga rebunshirensis and of Hokkaido (B) showing the range of $S$. yuparensis (red; square), S. rebunshirensis (blue; circle), and S. nishidae (green; triangle). (the map image from Google Earth). The figure is available in color online. 


\section{Material \& Methods}

\section{Molecular analyses}

\section{Taxon sampling}

Molecular phylogenetic analyses were conducted using samples of our collection and DNA sequence data from GenBank (Table 1). Saxifraga yuparensis grows on a rocky scree of Mt. Yubari and has only two patches $(0.3 \mathrm{x} 0.2$ $\mathrm{m}$ and $0.5 \times 1.5 \mathrm{~m}$ ), being located only ca. $5 \mathrm{~m}$ away from each other. One sample from each of the two patches (two samples in total) was collected to avoid collecting the same clones because this species can propagate vegetatively (authors' observation). DeChaine et al. (2013) sequenced a sample of "S. nishidae" (RBGE-E00295524) but we identified this specimen as $S$. yuparensis based on leaf apex morphology and found that the specimen was confused and mislabeled with genuine $S$. nishidae (RBGE-E00295525) collected on the same day on Mt. Yubari. The data of " $S$. nishidae" (RBGE-E00295524) was used for S. yuparensis. Saxifraga nishidae has more than 100 patches on a nearby rocky cliff of greenschist of Mt. Yubari. Six samples were collected from different patches with at least $5 \mathrm{~m}$ interval. In Mt. Yubari, S. rebunshirensis (Ken Sato 85.0207 in SAPS, Appendix) had been collected more than 30 years ago from Rosoku-iwa, that is several kilometers away from the rocky place where S. yuparensis and S. nishidae grow; but this time we could not collect the species there. We did not conduct DNA extraction/PCR with the herbarium specimen because the specimen was old and we were afraid to damage the valuable specimen in vain. Instead, two samples each from two localities in Hokkaido, Rebun Island and Mt. Nishi-Kumaneshiri, were used. Also, two plants from Mt. Hakuba in central Japan were hired. GenBank data for S. rebunshirensis from Moneron Island to the south of Sakhalin (UBC-V164570) were also used. To elucidate the phylogenetic positions of these three species, we incorporated allied 16 species of sect. Bronchiales (DeChaine et al. 2013) in the analyses. In Russian Far East, we collected $S$. ascoldica Sipliv. (1971: 156) in Primorsky Krai and S. cherlerioides D.Don (1822: 382) and S. funstonii (Small) Fedde (1905: 613 ) in Kamchatka. For the other species, DNA sequence data were obtained from GenBank. Distribution of the 19 species covered the whole distribution of sect. Bronchiales. For outgroups, two species of sect. Gymnopera D.Don (1822: 343) and one species of sect. Cymbalaria Griseb. (1843: 336) were selected (Table 1), following the result of Tkach et al. (2015).

\section{DNA extraction and sequencing}

Total genomic DNA was extracted from fresh leaves using the cetyltrimethyl ammonium bromide (CTAB) method (Doyle \& Doyle, 1987) with some modifications. Preceding phylogenetic studies on Saxifraga employed internal transcribed spacer (ITS) of nuclear ribosomal DNA (nrDNA) and trnL-F intergenic spacer of chloroplast DNA (cpDNA) (DeChaine et al. 2013, Tkach et al. 2015). We used primers following these preceding studies: trnL(UAA)

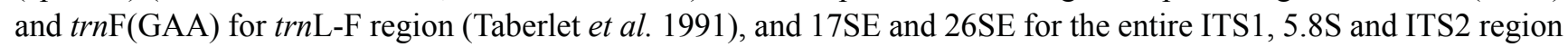
(Sun et al. 1994). PCR was performed in $25 \mu 1$ total volume with the following reagents: about 10 ng of genomic DNA, 1 unit of Taq DNA polymerase master mix (Ampliqon, Rødovre, Denmark), $0.4 \mu \mathrm{M}$ of each primer, and $4 \%$ DMSO. After an initial heating step at $94^{\circ} \mathrm{C}$ for $3 \mathrm{~min}$, samples were incubated for 25 cycles of $94^{\circ} \mathrm{C}$ for $1 \mathrm{~min}, 60^{\circ} \mathrm{C}$ (ITS) or $52^{\circ} \mathrm{C}(\operatorname{trn} \mathrm{L}-\mathrm{F})$ for $1 \mathrm{~min}, 72^{\circ} \mathrm{C}$ for $2 \mathrm{~min}$, with final extension at $72^{\circ} \mathrm{C}$ for $5 \mathrm{~min}$. The cycle sequencing reaction was carried out with a Big Dye Terminator Cycle Sequencing Kit ver. 3.1 (Applied Biosystems, Foster City, CA, USA) with the same primers used in the PCR. Direct sequencing was performed on an ABI Prism 3130 DNA analyzer (Applied Biosystems). The sequence data were deposited in DDBJ (DNA Data Bank of Japan) database (2017, Table 1).

\section{Phylogenetic analyses}

DNA sequences were aligned using ClustalX ver. 1.8 (Thompson et al. 1997) implemented in BioEdit ver. 7.2.5 (Hall 1999) and then manually adjusted. Phylogenetic analyses were based on a maximum parsimony (MP) criterion using PAUP* ver. 4.0b10 (Swofford 2002) and a Bayesian approach using MrBayes ver. 3.2 (Ronquist et al. 2012).

In the Bayesian phylogenetic analysis, MrModeltest 2.3 (Nylander 2008) was used to estimate the appropriate evolutionary model of nucleotide substitution based on the Akaike Information Criterion (AIC). Based on the model selected, two separate runs of Metropolis coupled Markov chain Monte Carlo (MCMCMC) analyses were performed, each with a random starting tree and four chains (one cold and three heated). The MCMCMC length was one million generations, and the chain was sampled every one hundredth generation from the cold chain. The mixing and convergence of the MCMC chains of the two runs was assessed by inspection of the trace plots of parameters using Tracer ver. 1.6 (Rambaut et al. 2013). The first 250 sample trees (2.5\% of the total 10,000 sample trees) were discarded as burn-in. After the burn-in, the effective sample sizes (ESS) of all parameters were more than 500, indicating that 


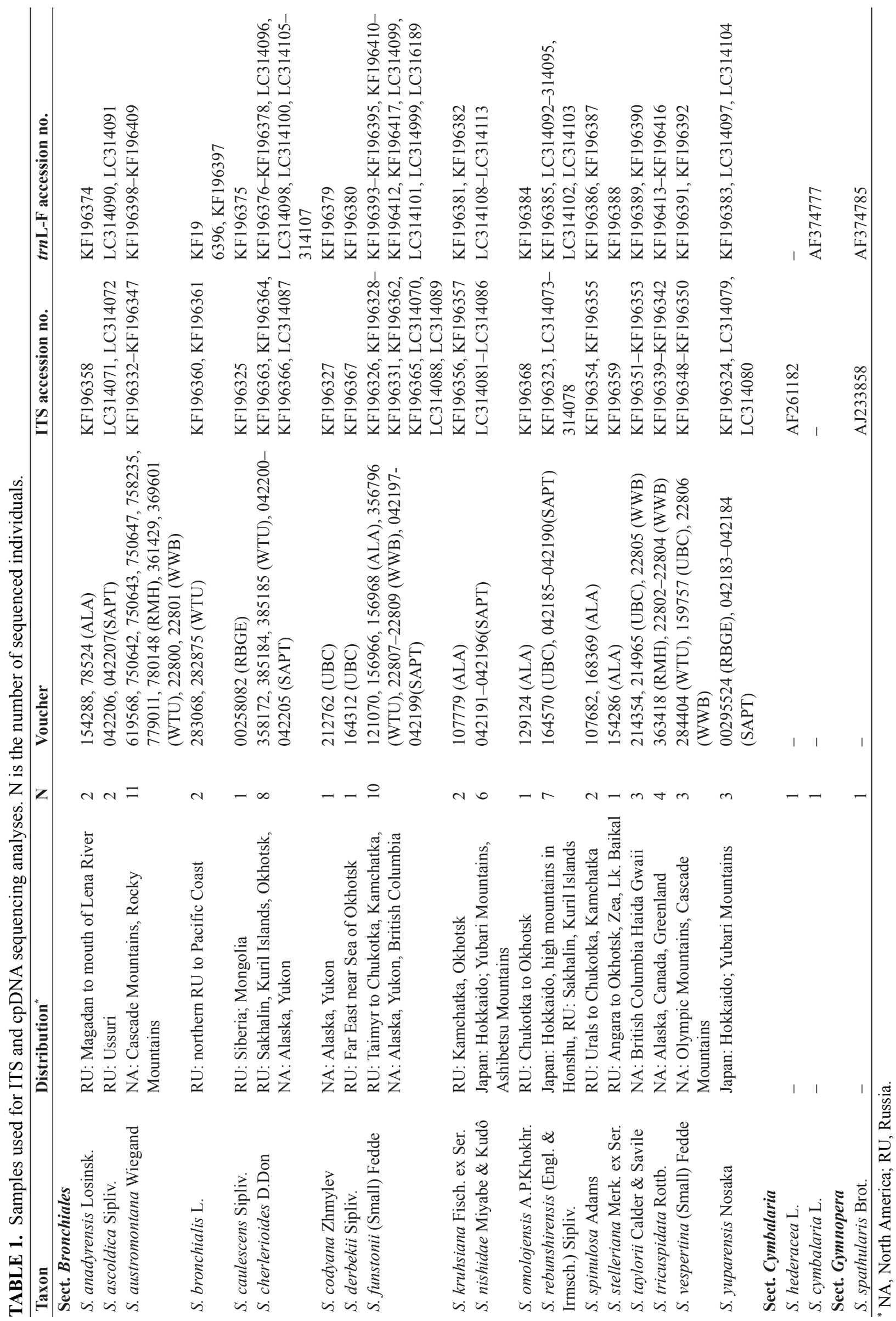


the analyses sampled the posterior distributions of each parameter satisfactorily, and the values of Average Standard Deviation of Split Frequency (ASDSF) were below 0.008 . The 50\% majority rule consensus tree and Bayesian posterior probabilities $(P P)$ of all the post-burn-in trees was generated using FigTree ver. 1.4.2 (Rambaut 2014).

In the MP phylogenetic analysis, indels were treated as missing data. The characters were treated as unordered, and the character transformations were weighted equally. The branch collapse option was set to collapse at a minimum length of zero. A heuristic parsimony search was performed with 1000 replicates of random additions of sequences with ACCTRAN character optimization, tree bisection-reconnection (TBR) branch swapping, and MULTREES and STEEPEST DESCENT options on. Statistical support for each clade was assessed by bootstrap analysis (Felsenstein 1985). One thousand replicates of heuristic searches, with the TBR branch swapping switched on and MULTREES options off, were performed to calculate bootstrap percentages $(B P)$.

\section{Genome-wide SNP analysis}

To test the immediate hybridity and species relationships based on multiple independent nuclear loci, genome-wide SNP detection was conducted with the focal three species. The samples of our own collection used in the sequencing analysis were employed. Preceding studies (Rutledge et al. 2015, Karimi et al. 2016) based on genome-wide SNP data (observed and simulated data) successfully indicated that hybrids were plotted at the intermediate between the parental species in a principal coordinate analysis (PCA) (e.g., F1 and F2 individuals occurred at intermediate between the two parental species, and backcross individuals occurred between the F1 and the one parental species; Rutledge et al. 2015). For SNP detection, we employed a method MIG-seq [i.e., multiplexed inter simple sequence repeats (ISSRs) Genotyping by sequencing; Suyama \& Matsuki 2015]. MIG-seq is a type of reduced representation sequencing, where ISSRs are amplified by multiplex PCR. Thereby the method is more applicable to low-quality genomic DNA than RADseq. Most of SNPs obtained by MIG-seq are putatively selectively neutral because these are immediately adjacent to two repeat regions (Takahashi et al. 2016). Highly reduced representation libraries were constructed following Suyama \& Matsuki (2015) and sequenced on an Illumina MiSeq sequencer (Illumina, San Diego, CA, USA). Both ends of the fragments were read by paired-end sequencing.

Sequences of reads were quality-filtered using FASTX-Toolkit (http://hannonlab.cshl.edu/fastx_toolkit/), with the settings of $q=30$ and $p=40$. The quality-filtered reads were then bundled together to form putative loci (stacks) with the software Stacks v1.15 (Catchen et al. 2013) using the 'ustacks' option, with the settings of minimum depth of coverage required $(m)=20$, maximum distance between stacks $(M)=2$, and the deleveraging $(d)$ and removal $(r)$ algorithms enabled. Using the 'cstacks' option, a catalog was created for all possible loci and alleles with the parameter 'number of allowed mismatches between samples $(n)$ ' $=4$. The stacks created by 'ustacks' were then searched against the catalogue using the 'sstacks' option. The data set of all the samples was considered as a single population and SNPs were retrieved using the 'populations' option, with the 'write_single_snp' option to select only the first SNP per locus to avoid the linkage between SNPs. Only loci that were shared among at least $75 \%$ of the samples were considered. If a locus was not recovered in a sample, the genotype of the sample was treated as missing data. PCA of SNP genotypes was conducted using GENODIVE (Meirmans \& Van Tienderen 2004) with the default parameter settings.

\section{Chromosome observation}

For chromosome observation, we used four individual of Saxifraga yuparensis from Mt. Yubari (Saya Tamura 992, 993, 994, 995, SAPT), four individuals of S. rebunshirensis from Mt. Nishi-kumaneshiri (Saya Tamura 434, 436, SAPT) and Rebun Island (Saya Tamura 328, 329, SAPT) of Hokkaido, and four individuals of S. nishidae from Mt. Yubari (Saya Tamura 996, 997, 998, 999, SAPT). Plant materials were collected in the field and cultivated in Botanic Garden, Hokkaido University. The methods for the observation of somatic chromosome numbers followed Fukuda et al. $(2007,2016)$ with some modifications. Root tips were pretreated in $0.002 \mathrm{M} 8$-hydroxyquinoline solution for 10 hours at $4^{\circ} \mathrm{C}$, and fixed in Farmer's solution (glacial acetic acid: $99 \%$ ethanol $=1: 3$ ) for more than 16 hours at $4^{\circ} \mathrm{C}$. Then the root tips were macerated in $1 \mathrm{~N} \mathrm{HCl}$ for 10 minutes at $60^{\circ} \mathrm{C}$, stained with $1 \%$ aceto-orcein for 10 minutes, and squashed. Chromosomes were observed under a binocular Zeiss Axio Imager A1 microscope (Carl Zeiss SpA, Italy), and photomicrographs were taken using a Anyty 3R-DKMC01 camera (3R solution corporation, Japan).

\section{Morphological observation}

A diagnostic character of leaf apex shape was observed in the three species. Typically, S. rebunshirensis has cuspidate leaves while S. nishidae has tricuspidate leaves; and S. yuparensis has slightly tricuspidate leaves (Shimizu 1983, Ohba 
1999, Wakabayashi 2001, Shimizu 2014, Okuyama 2016). Herbarium specimens of the three species (Appendix) were examined in the herbaria of Hokkaido University Museum (SAPS), Botanic Garden, Hokkaido University (SAPT) and the National Museum of Nature and Science (TNS) to elucidate the variability of the diagnostic character especially within $S$. rebunshirensis, that has large species range.

\section{Results}

Phylogenetic relationships based on ITS

The aligned length of the ITS data was $822 \mathrm{bp}$. In S. rebunshirensis, five sequence types were recognized among the seven samples, and $S$. nishidae had two sequence types in the six samples. The two samples of $S$. yuparensis of our collection (SAPT-042183, 042184) showed one type of sequence with a double-peak signal (adenin and guanin) at one site (position 423 in the registered sequences) in the sequence chromatogram, while all the samples of $S$. rebunshirensis and $S$. nishidae had only adenin but not guanin at the same site. This site was coded as R in the two $S$. yuparensis samples. In the Bayesian analysis, the AIC selected the $\mathrm{SYM}+\mathrm{I}+\mathrm{G}$ model. The $50 \%$ majority rule consensus tree of all the post-burn-in trees is depicted (Fig 3). In the MP analysis, 201 nucleotide substitutions were found in 57 variable sites and 114 sites were parsimony informative among them. 15,104 equally parsimonious trees of 314 steps were obtained with a consistency index $(\mathrm{CI})=0.78$, a retention index $(\mathrm{RI})=0.91$, and a resealed consistency index $(\mathrm{RC})=0.71$. The topology of the strict consensus tree was the same as that of the Bayesian tree, and therefore $B P \mathrm{~s}$ of the MP analysis are plotted on the Bayesian tree (Fig 3). In the following, only clades with $P P \geq 0.95$ and/or $B P \geq$ $70 \%$ were considered adequately supported. The phylogenetic tree had moderate resolution and supported monophyly for several species, including $S$. nishidae $(P P=1.00 / B P=100)$. On the other hand, monophyly was not supported for each S. yuparensis and S. rebunshirensis; the two species were included in a clade $(1.00 / 55.4)$ with a portion of samples (three samples) of S. funstonii and S. caulescens Sipliv. (1971: 151). This clade was nested within a clade with the other five samples of S. funstonii and one S. codyana (1.00 / 66.3). Thereby, S. yuparensis plus S. rebunshirensis were phylogenetically distinct from $S$. nishidae.

Phylogenetic relationships based on $\operatorname{trn} \mathrm{L}-\mathrm{F}$

The aligned length of the trnL-F data was $446 \mathrm{bp}$. All the samples of $S$. rebunshirensis and S. yuparensis had the same sequence, that was shared with other 11 species in the same clade (below). In the six samples of S. nishidae, only one type of sequence was recovered. In the Bayesian analysis, the AIC selected the GTR model. The $50 \%$ majority rule consensus tree of all the post-burn-in trees is depicted (Fig 4). In the MP analysis, 28 nucleotide substitutions were found in 12 variable sites and 13 sites were parsimony informative among them. 574,318 equally parsimonious trees of 30 steps were obtained with $\mathrm{CI}=1$. The topology of the strict consensus tree was the same as that of the Bayesian tree, and therefore $B P$ s of the MP analysis are plotted on the Bayesian tree (Fig 4). While the phylogenetic tree largely had low resolution, but nevertheless $S$. nishidae formed a well-supported clade $(1.00 / 97.2)$, and this clade was sister to a portion of samples (three samples) of $S$. austromontana (0.97 / 63.0). In contrast, each $S$. yuparensis and $S$. rebunshirensis was not monophyletic; these two species were recovered in the same polyphyletic clade $(0.98 / 61.1)$ with other 11 species.

Species relationships based on genome-wide SNPs

The resultant data set comprised 699 SNP loci. The result of the PCA based on the SNP genotyping data is shown (Fig. 5). The first and second principal components explained $51.6 \%$ and $11.5 \%$ of the variances. The SNP genotyping data clearly separated the three species in the principal coordinate space; the plots of $S$. nishidae were separated from $S$. yuparensis and S. rebunshirensis along the first principal coordinate, and those of S. yuparensis and S. rebunshirensis were distinguished along the second principal coordinate. Note that $S$. yuparensis was not placed in-between of $S$. rebunshirensis and $S$. nishidae. 


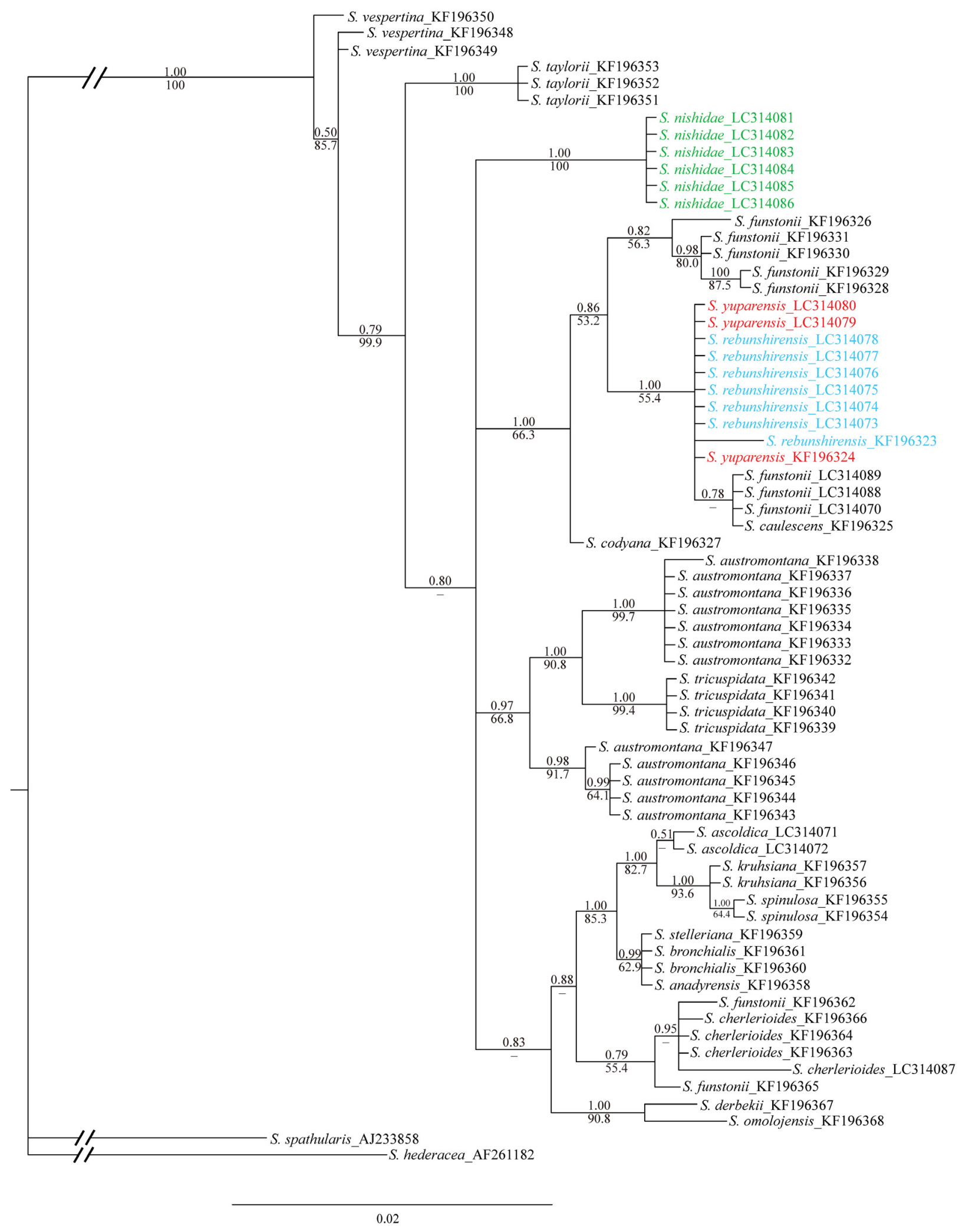

FIGURE 3. Bayesian majority-rule consensus tree of Saxifraga sect. Bronchiales based on ITS. The numerals on branches are Bayesian posterior probabilities (PP: upper) and bootstrap percentages (BP: lower) in the MP analysis. The figure is available in color online. 


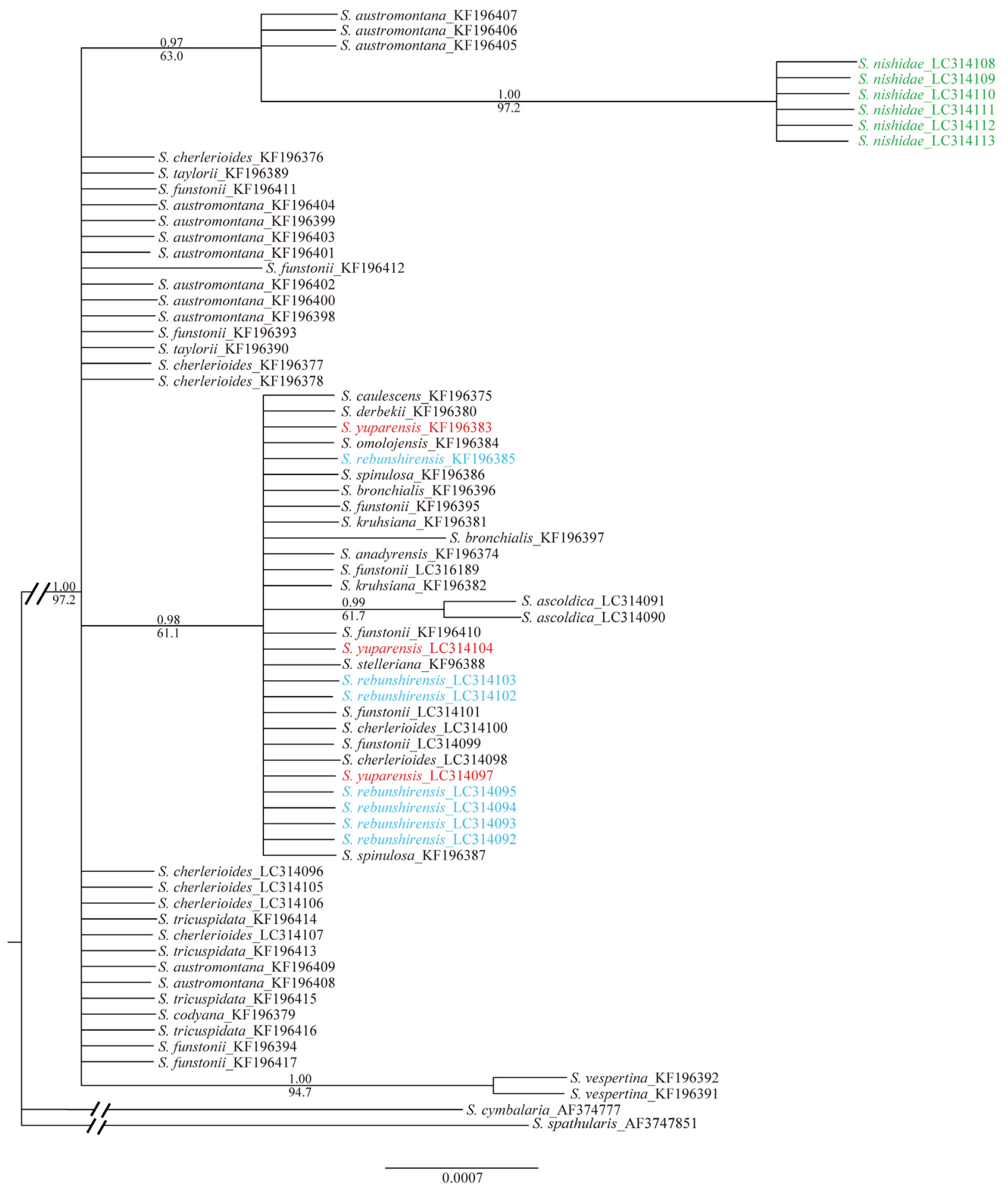

FIGURE 4. Bayesian majority-rule consensus tree of Saxifraga sect. Bronchiales based on trnL-F. The numerals on branches are Bayesian posterior probabilities ( $P P$ : upper) and bootstrap percentages ( $B P$ : lower) in the MP analysis. The figure is available in color online.

Chromosome number

The chromosome number of $S$. yuparensis was first determined as $2 \mathrm{n}=48$ (Fig 6-A \& D). In S. rebunshirensis the chromosome number was $2 n=48$ in all the three individuals examined (Fig 6-B \& E) and this is the same as reported by Sakai (1935) but different from the number reported by Funamoto \& Nakamura (1990) $(2 n=50)$. The chromosome number of $S$. nishidae was $2 \mathrm{n}=26$ in all the four individuals (Fig 6-C \& F), and that was the same as reported by Funamoto \& Nakamura (1993). 


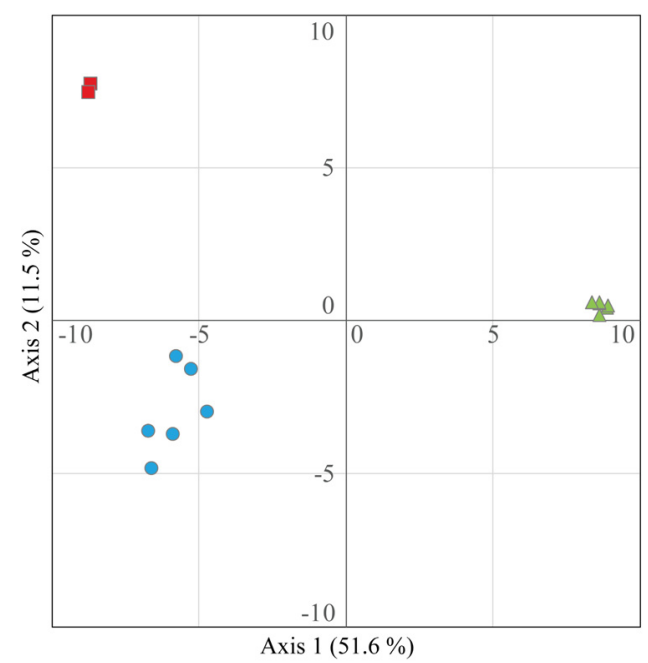

FIGURE 5. Plots of principal coordinate analysis (PCA) based on genome-wide SNPs of Saxifraga yuparensis (red; square), S. rebunshirensis (blue; circle), and S. nishidae (green; triangle). The figure is available in color online.

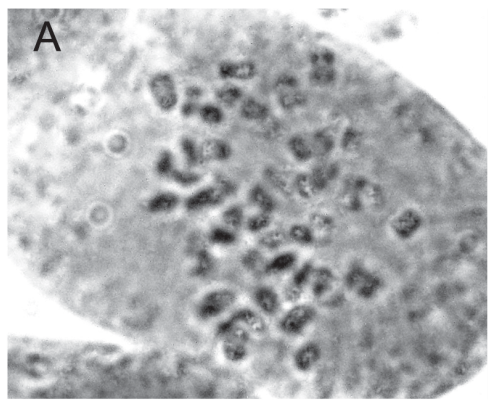

D

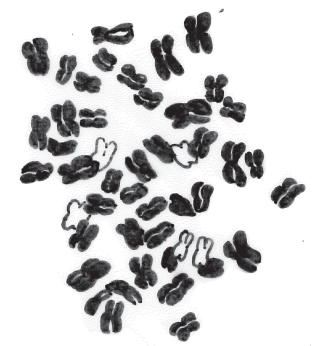

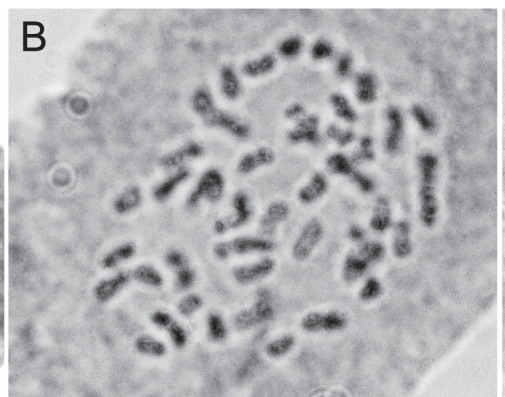

$\mathrm{E}$

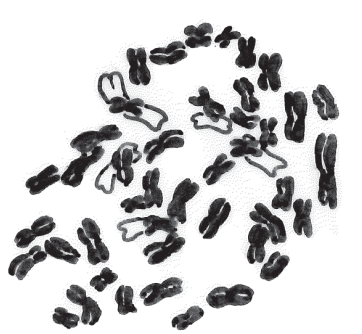

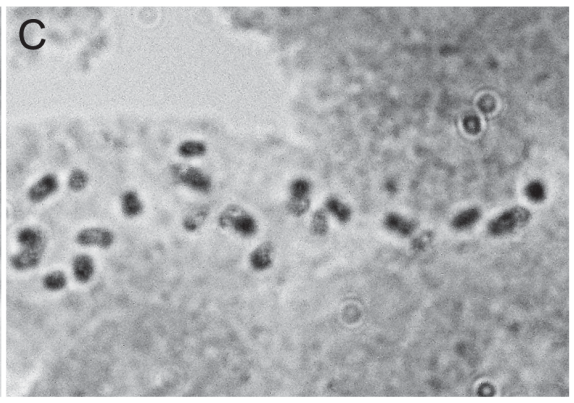

$\mathrm{F}$

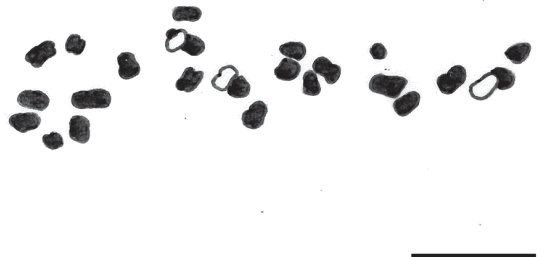

FIGURE 6. Photomicrographs of somatic metaphase chromosomes of Saxifraga yuparensis (A), S. rebunshirensis (B) and S. nishidae (C). D, E and F are explanatory drawings of A, B and C, respectively. Scale bar represents $5 \mu \mathrm{m}$.

Variability of leaf apex morphology

All the 14 specimens examined for $S$. yuparensis had slightly tricuspidate leaf apex except for leaves on flowering stems (Fig 7-A \& D, Appendix). In S. rebunshirensis, 199 out of 213 specimens examined had cuspidate leaves (Fig 7-B \& E, Appendix) but 14 specimens collected from Hokkaido, Honshu, and Sakhalin had slightly tricuspidate leaves on vegetative stems (Fig 7-F, Appendix). On the other hand, all the 26 specimens of S. nishidae had conspicuously tricuspidate leaf apex except for ones on flowering stems (Fig 7-C \& G, Appendix), and the specimens of S. nishidae were clearly distinguished from the other two species. 


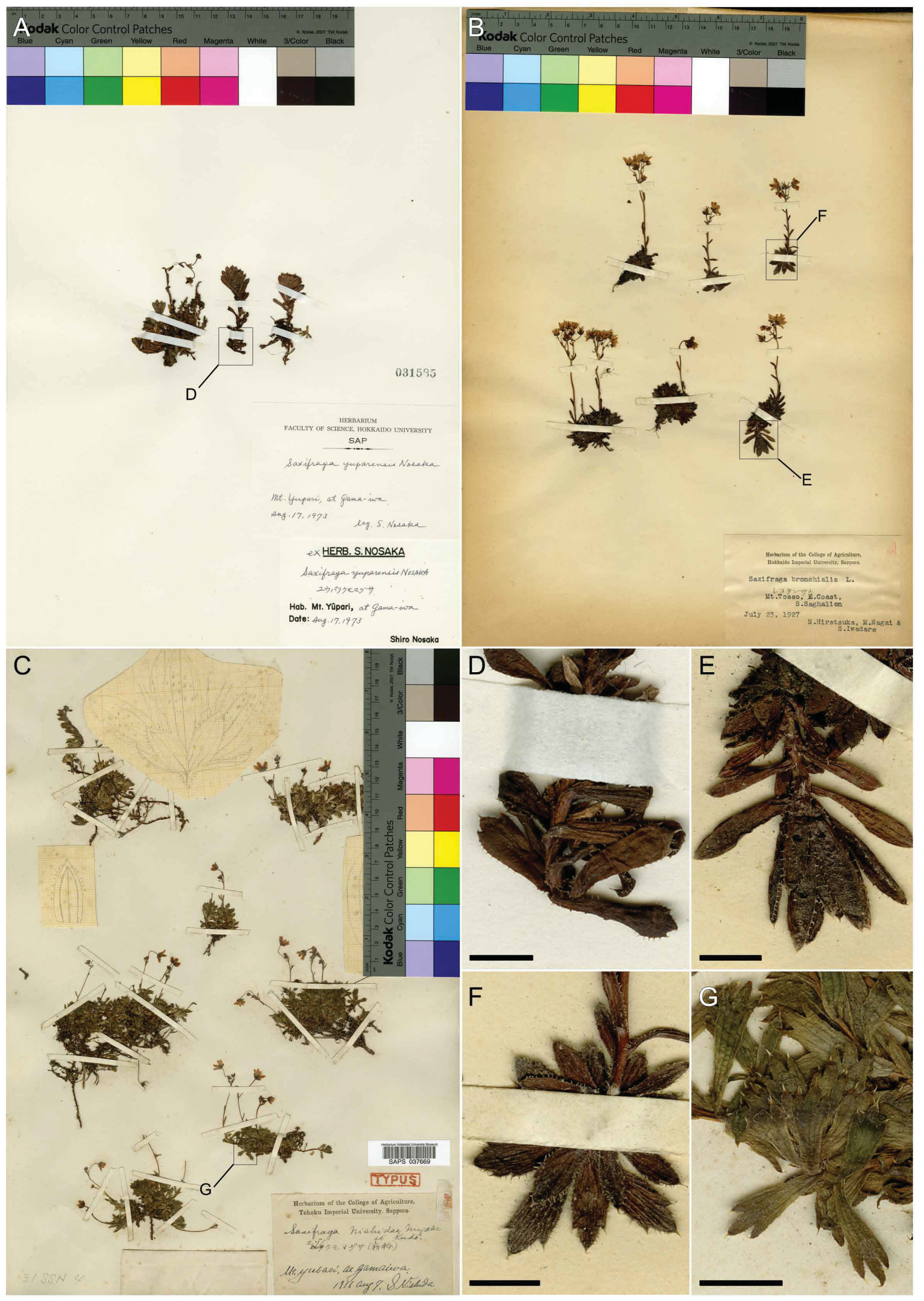

FIGURE 7. Specimens of Saxifraga yuparensis (A \& D), S. rebunshirensis (B, E \& F), and S. nishidae (C \& G). Scale bars are 5 mm for $\mathrm{D}-\mathrm{G}$. The figure is available in color online. 


\section{Discussion}

In the molecular phylogenetic analyses based on ITS and cpDNA, S. yuparensis was not monophyletic and recovered in the same clade with $S$. rebunshirensis plus several other species (S. funstonii and S. caulescens in ITS; 11 species in $\operatorname{trn} \mathrm{L}-\mathrm{F})$. On the other hand, S. nishidae formed a well-supported monophyletic clade in both ITS and cpDNA, and this clade was distinct from the clades including S. yuparensis and S. rebunshirensis. If S. yuparensis were a hybrid derivative of the two species, two distinct sequences from each of the $S$. yuparensis samples would be recovered in both the clades of $S$. rebunshirensis and S. nishidae in the ITS phylogeny, although it cannot be excluded that the ITS allele of one parental species (here $S$. rebunshirensis) became dominant by concerted evolution via unequal crossingover and gene conversion through time (given that $S$. yuparensis is not an immediate but old hybrid). However, the PCA based on the SNP genotyping data clearly separated the three species and S. yuparensis samples were not placed in-between of $S$. rebunshirensis and $S$. nishidae. This result, being based on multiple independent nuclear loci, also negate the hybrid hypothesis of $S$. yuparensis. The result also likely negates the scenario that ITS allele of $S$. rebunshirensis became dominant by concerted evolution in S. yuparensis. Chromosome observation revealed that $S$. yuparensis is tetraploid. If it were an immediate hybrid derived from diploid-tetraploid crossing, it would be triploid. Thus, the chromosome data negate, at least, the immediate hybridity. Considered in a comprehensive way, all the results based on ITS and cpDNA sequences, genome-wide SNPs, and chromosome count negate the hypothesis that S. yuparensis is derived from hybridization between S. rebunshirensis and S. nishidae. Concerning the infertility of S. yuparensis, Shimizu (1983) reported that the seeds of S. yuparensis did not germinate, and we have not observed mature fruits in the wild population. The infertility of $S$. yuparensis is probably caused by self-incompatibility, not by triploidy. Self-incompatibility in Saxifraga was reported for species of the same section Bronchiales (Goertzen 1996). Currently there are two patches of S. yuparensis at Mt. Yubari but these patches were originally one patch, that were subsequently fragmented by rock debris (authors' observation), and the two patches likely contain very closely related plants such as those of the same sibling that are incompatible.

Concerning the taxonomic treatment of $S$. yuparensis, the SNP analysis suggests that $S$. yuparensis is a lineage distinct from $S$. rebunshirensis. Note, however, that $S$. rebunshirensis itself has taxonomic problems and is sometimes treated as a subspecies or variety of S. cherlerioides, S. bronchialis L. (1753: 400), or S. funstonii (Engler et al. 1919, Hara 1937, Hara 1952, Toyokuni 1975, Takahashi 2015b). The present phylogenetic analyses are not conclusive about the species relationships because monophyly was not supported for each of these species and because the trees lacked necessary resolution. The SNP analysis did not include the other species treated in the phylogenetic analyses, specifically S. funstonii and $S$. caulescens clustered with $S$. yuparensis and S. rebunshirensis in the ITS tree (and in the cpDNA tree with the other nine species, although it showed lower resolution). Full revision of their taxonomy needs more intensive analysis of the allied species using genome-wide SNPs, but it is beyond the scope of the present study (i.e., test on the hybrid hypothesis). When we follow the idea to treat $S$. rebunshirensis as an independent species (Siplivinsky 1971; DeChaine 2014), what is the diagnostic character to separate it from S. yuparensis? Slightly tricuspidate leaf is a character based on which $S$. yuparensis has been distinguished from S. rebunshirensis. In the morphological observations of specimens, it was revealed that S. rebunshirensis from Hokkaido, Honshu, and Sakhalin sometimes had slightly tricuspidate leaves. The leaf apex shape of $S$. yuparensis fell within the variation of S. rebunshirensis and thereby is not a diagnostic character. In addition, Barkalov (2009) conducted morphological comparison between $S$. yuparensis from Mt. Yubari and S. rebunshirensis samples from the southern Kuril Islands, where S. yuparensis is not reported and which should be treated as S. rebunshirensis (Charkevics 1989; Takahashi 2015b); he recognized no morphological difference. According to literature, another diagnostic character of S. yuparensis and S. rebunshirensis is a conspicuous claw of petal base in the former species, that is lacked in the latter species (Nosaka 1980; Shimizu et al. 2014), while Barkalov (2009) did not mention the character. Although it was difficult to examine the character with dried herbarium specimens, by observing living plants in wild and botanic gardens, we also recognized the difference in the two species (authors' observations, Appendix).

In conclusion, S. yuparensis is not an immediate hybrid of S. rebunshirensis and S. nishidae but a distinct lineage, as was revealed by the DNA sequence, genome-wide SNP, and cytological evidences. This is an extremely narrow endemic species, that is morphologically distinguished from the congeners in Hokkaido by having a claw of petal base, and deserves for intensive conservation. 


\section{Acknowledgement}

We thank Seiichiro Miyamato, Minori Somada, Kenji Murakami, and Shogo Kikuta for assistance in field sampling and Hiroyuki Sato for help in herbarium work. This study was supported in part by Grants-in-Aid for Scientific Research, KAKENHI to K.N. (16K18596) and a research grant from the Mitsui \& Co. Environment Fund to K.N. (R15-0067).

\section{Reference}

Barkalov, V.Y. (2009) Flora of the Kuril Islands. Dalnauka, Vladivostok, 468 pp.

Catchen, J., Hohenlohe, P., Bassham, S., Amores, A. \& Cresko, W. (2013) Stacks: an analysis tool set for population genomics. Molecular Ecology 22 (11): 3124-3140.

https://doi.org/10.1111/mec.12354

Charkevicz, S.S. (1989) Saxifragaceae. In: Charkevicz, S.S. (Ed.) Plantae vasculares orientis extremi sovietici 4. NAUK, Moscow, pp. $122-190$.

DDBJ (2017) DNA Data Bank of Japan, National Institute of Genetics, Japan, Mishima. Available from: http://www.ddbj.nig.ac.jp/ (accessed 19 August 2017)

DeChaine, E.G., Anderson, S.A., McNew, J.M. \& Wendling, B.M. (2013) On the evolutionary and biogeographic history of Saxifraga sect. Trachyphyllum (Gaud.) Koch (Saxifragaceae Juss.). PloS one 8: e69814. https://doi.org/10.1371/journal.pone.0069814

DeChaine, E.G. (2014) Introducing the Spotted Saxifrages: Saxifraga Sect. Bronchiales, Sect. Nov. (Saxifragaceae). Rhodora 116: 2540 . https://doi.org/10.3119/13-09

Don, D. (1822) Monograph of the genus Saxifraga. Transactions of the Linnean Society of London 13: 341-452. https://doi.org/10.1111/j.1095-8339.1821.tb00066.x

Doyle, J.J. \& Doyle, J.L. (1987) A rapid DNA isolation procedure for small quantities of fresh leaf tissue. Phytochemistry Bulltein 19: $11-15$.

Engler, H.G.A. \& Irmscher, E. (1919) Saxifragaceae-Saxifraga. In: Engler, H.G.A. (Ed.) Das Pflanzenreich 69 (IV. 117. II) Wilhelm Engelmann, Leipzig, pp. 449-709.

Fedde, F. (1905) Novorum generum, specierum, varietatum, formarumque Siphonogamarum index. Just's Botanischer Jahresbericht 33 : 613.

Felsenstein, J. (1985) Confidence limits on phylogenies: an approach using the bootstrap. Evolution 39: 783-791. https://doi.org/10.1111/j.1558-5646.1985.tb00420.x

Fukuda, T., Naiki, A. \& Nagamasu, H. (2007) Karyotypic analysis of Skimmia japonica (Rutaceae) and related species. Journal of Plant Research 120 (1): 113-121. https://doi.org/10.1007/s10265-006-0033-4

Fukuda, T., Andreeva, E., Taran, A., Takahashi, H. \& Ikeda, H. (2016) Chromosome number of Micranthes nelsoniana (D. Don) Small (Saxifragaceae) in northeast Asia. Caryologia 69 (4): 325-329.

Funamoto, T. \& Nakamura, T. (1990) Notes on somatic chromosome numbers in Japanese Saxifraga (1). Chromosome Information Service 49: 4-6.

Funamoto, T. \& Nakamura, T. (1993) Notes on somatic chromosome numbers in Japanese Saxifraga (2), Karyotypes of four alpine Saxifraga species. La Kromosomo 70: 2412-2416.

Goertzen, L.R. (1996) Genetic diversity and origin of two queen charlotte islands plants: Senecio newcombei and Saxifraga taylori. Master Thesis, University of British Columbia, Vancouver. $62 \mathrm{pp}$.

Grisebach, A.H.R. (1843) Spicilegium florae rumelicae et bithynicae exhibens synopsin plantarum quas in aest., volume 1. Vieweg \& Son, Brunsvigae, $407 \mathrm{pp}$.

Hall, T.A. (1999) BioEdit: a user-friendly biological sequence alignment editor and analysis program for Windows 95/98/NT. Nucleic Acids Symposium Series 41: 95-98.

Hara, H. (1937) Observations ad plantas asia orientalis XIII. Journal of Japanese Botany 13: 174.

Hara, H. (1952) Contributions to the study of variations in the Japanese plants closely related to those of Europe or North America. Part 1. Journal of the Faculty of Science University of Tokyo, Section III (Botany) 6: 29-96.

Hokkaido (2001) Hokkaido red list (plants). Hokkaido Government, Sapporo, 10 pp. Available from: http://www.pref.hokkaido.lg.jp/ks/ skn/grp/03/redlist1.pdf (accessed 20 August 2017) 
Iwatsuki, K. \& Kato, T. (1994) Red data plants-a pictorial of Japanese flora facing extinction. Takarajimasha, Tokyo, 208 pp.

Karimi, K., Strucken, E., Moghaddar, N., Ferdosi, M., Esmailizadeh, A. \& Gondro, C. (2016) Local and global patterns of admixture and population structure in Iranian native cattle. BMC Geneticsgenetics 17 (1): 108. https://doi.org/10.1186/s12863-016-0416-z

Koch, W.D.J. (1836) Synopsis florae Germanicae et Helveticae. Wilmans, Frankfurt, 844 pp.

Linnaeus, C. (1753) Species Plantarum 1. Laurentii Salvii, Holmiae, 560 pp.

Meirmans, P.G., Van Tienderen, P.H. (2004) GENOTYPE and GENODIVE: two programs for the analysis of genetic diversity of asexual organisms. Molecular Ecology Resources 4 (4): 792-794. https://doi.org/10.1111/j.1471-8286.2004.00770.x

Ministry of the Environment, Government of Japan (2017) Ministry of the Environment red list 2017. Tokyo, Ministry of the Environment, Government of Japan. Available from: http://www.env.go.jp/press/files/jp/105449.pdf (accessed 20 August 2017)

Miyabe, K. \& Kudô, Y. (1917) Materials for a flora of Hokkaido VII. Sapporo Natural History Society 6: 170-171.

Murata, G. (1961) Saxifragaceae. In: Kitamura, S. \& Murata, G. (Eds.) Colored illustrations of herbaceous plants of Japan (Choripetalae), Hoikusha, Osaka, pp. 136-157.

Nakagawa, H. \& Sato, K. (2015) A new Locality of Saxifraga nishidae (Saxifragaceae) from Hokkaido, Japan. Journal of Japanese Botany 90: $356-358$

Nishikawa, Y., Miyaki, M. \& Hori, S. (1992) Community formations of Saxifraga yuparensis and S. nishidae in the rocky ridge region of Mt. Yubari. Report of Hokkaido Institute of Environmental Sciences 19: 61-66.

Nosaka, S. (1974) The Phanerogam Flora of Mt. Yûpari, Prov. Ishikari, Hokkaido, Japan. Journal of the Faculty of Science, Hokkaido University Series 5 Botany 9: 55-300.

Nosaka, S. (1980) The plants of genus Saxifraga in Hokkaido. Hoppousansou 1: 2-10.

Nylander, J.A.A. (2008) MrModeltest 2.3. Department of Systematic Zoology, Uppsala University. Uppsala.

Ohba, H. (1999) Saxifragaceae. In: Satake, Y., Kitamura, S., Tominari, T., Ohwi, J. \& Watari, S. (Eds.) Wild flowers of Japan II. Heibonsha, Tokyo, pp. 153-172.

Okuyama, Y. (2016) Saxifragaceae. In: Ohashi, H., Kadota, Y., Kihara, H., Murata, J. \& Yonekura, K. (Eds.) Wild flowers of Japan II revised new edition. Heibonsha, Tokyo, pp. 210-212.

Rambaut, A., Drummond, A.J. \& Suchard, M. (2013) Tracer v1.6: MCMC Trace Analysis Package. Institute of Evolutionary Biology, University of Edinburgh, UK. Available from: http://tree.bio.ed.ac.uk/software/tracer/ (accessed 20 August 2017)

Rambaut, A. (2014) FigTree 1.4.2 software, Institute of Evolutionary Biology, University of Edinburgh. Available from: http://tree.bio. ed.ac.uk/software/figtree/ (accessed 20 August 2017)

Ronquist, F., Teslenko, M., van der Mark, P., Ayres, D.L., Darling, A., Höhna, S., Larget, B., Liu, L., Suchard, M.A. \& Huelsenbeck, J.P. (2012) MrBayes 3.2: efficient Bayesian phylogenetic inference and model choice across a large model space. Systematic Biology 61: $539-542$.

https://doi.org/10.1093/sysbio/sys029

Rutledge, L.Y., Devillard, S., Boone, J.Q., Hohenlohe, P.A. \& White, B.N. (2015) RAD sequencing and genomic simulations resolve hybrid origins within North American Canis. Biology Letters 11 (7): 20150303.

https://doi.org/10.1098/rsbl.2015.0303

Sakai, K. (1935) Studies on the chromosome number in alpine plants II. Genetics 9: 226-230.

Sato, K. (2007) Geobotanical study on the alpine vegetation of Hokkaido, Japan. Hokkaido University Press, Sapporo, 688 pp.

Shimizu, T. (1983) The new alpine flora of Japan in color II. Hoikusha, Tokyo, 331 pp.

Shimizu, T., Kadota, Y. \& Kihara, H. (2014) Alpine flowers of Japan. Yama-kei Publishers, Tokyo, 512 pp.

Siplivinsky, V. (1971) Generis Saxifraga L. species asiaticae e sectione Trachyphyllum Gaud. Novitates Systematicae Plantarum Vascularium 8: 147-158.

Small, J.K. (1905) Saxifragaceae. In: Britton, N.L. (Ed.) North American flora. New York Botanical Garden, New York, pp. 81-158.

Soltis, D.E., Kuzoff, R.K., Mort, M.E., Zanis, M., Fishbein, M., Hufford, L., Koontz, J. \& Arroyo, M.K. (2001) Elucidating deep-level phylogenetic relationships in Saxifragaceae using sequences for six chloroplastic and nuclear DNA regions. Annals of the Missouri Botanical Garden 88: 669-693. https://doi.org/10.2307/3298639

Sun, Y., Skinner, D.Z., Liang, G.H. \& Hulbert, S.H. (1994) Phylogenetic analysis of Sorghum and related taxa using internal transcribed spacers of nuclear ribosomal DNA. Theoretical and Applied Genetics 89: 26-32. https://doi.org/10.1007/BF00226978

Suyama, Y., Matsuki, Y. (2015) MIG-seq: an effective PCR-based method for genome-wide single-nucleotide polymorphism genotyping using the next-generation sequencing platform. Scientific Reports 5: 16963.

https://doi.org/10.1038/srep16963 
Swofford, D.L. (2002) PAUP*: phylogenetic analysis using parsimony, version 4.0b10. Sinauer Associates, Sunderland. Available from: http://paup.sc.fsu.edu/ (accessed 20 August 2017)

Taberlet, P., Gielly, L., Pautou, G. \& Bouvet, J. (1991) Universal primers for amplification of three non-coding regions of chloroplast DNA. Plant Molecular Biology 17: 1105-1109. https://doi.org/10.1007/BF00037152

Takahashi, H. (2015a) Saxifraga yuparensis, Saxifraga nishidae. In: Yawara, T., Fujii, S., Ito, M. \& Ebihara, A. (Eds.) Red data plants. Yama-kei Publishers, Tokyo, pp. 314.

Takahashi, H. (2015b) Plants of the Kuril Islands. Hokkaido University Press, Sapporo, pp. 509.

Takahashi, Y., Suyama, Y., Matsuki, Y., Funayama, R., Nakayama, K., \& Kawata, M. (2016) Lack of genetic variation prevents adaptation at the geographic range margin in a damselfly. Molecular ecology 25: 4450-4460. https://doi.org/10.1111/mec.13782

Tkach, N., Röser, M., Miehe, G., Muellner-Riehl, A.N., Ebersbach, J., Favre, A. \& Hoffmann, M.H. (2015) Molecular phylogenetics, morphology and a revised classification of the complex genus Saxifraga (Saxifragaceae). Taxon 64: 1159-1187. https://doi.org/10.12705/646.4

Thompson, J.D., Gibson, T.J., Plewniak, F., Jeanmougin, F. \& Higgins, D.G. (1997) The CLUSTAL_X windows interface: flexible strategies for multiple sequence alignment aided by quality analysis tools. Nucleic Acids Research 25: 4876-4882. https://doi.org/10.1093/nar/25.24.4876

Toyokuni, H. (1975) Index plantarum in regionibus alpinis Hokkaidoensibus sponte crescentium 2. Journal of the Asahikawa University 3: 158.

Toyokuni, H. (1988) Alpine flowers of Japan. Yama-kei Publishers, Tokyo, 719 pp.

Umezawa, S. (2004) Flora of the Yubari \& Hidaka Range, Hokkaido. Hokkaido Shimbun Press, Sapporo, 239 pp.

Wakabayashi, M. (2001) Saxifraga L. In: Iwatsuki, K. Boufford, David, E. \& Ohba, H. (Eds.) Flora of Japan. Angiospermae, Dicotyledoneae, Archichlamydeae (b) vol IIb. Koudansha, Tokyo, pp. 54-55.

Watanabe, T. (1971) Phytogeographical studies of the alpine plants (vascular plants) on the Hidaka-Yubari ranges, Hokkaido. Memories of the National Science Museum 4: 95-126. 


\section{Appendix}

Herbarium specimens used for morphological observations. Specimens that were observed for petal shape are marked with daggers ( $\dagger$ ), and ones of Saxifraga rebunshirensis that had slightly tricuspidate leaves are marked with asterisks (*). Superscript letters (A-F) indicate scientific names (synonyms) or Japanese names on the labels, as shown in the footnote.

Saxifraga yuparensis: JAPAN. Hokkaido: Mt. Yubari Gamaiwa, 22-26 July 1928, Koidzumi Hideo 16910 (TNS). Mt. Yubari, July 1934, Ohwi Jizaburo 224482 (TNS). Mt. Yûpari Gama-iwa, 1 August 1967, Mikio Tohyama s.n. (SAPS). Mt. Yupari Gama-iwa, 17 August 1973, Shiro Nosaka 031584, 031585 (SAPS). Hokkaido: Mt. Yubari Gamaiwa, 6 August 1991, Ken Sato 91.1708, 91.1328, 91.1329 (SAPS). Mt. Yubari Gama-iwa, 26 July 2016, Saya Tamura 582 ${ }^{\dagger}$, $586^{\dagger}$ (SAPT). Mt. Yubari Gama-iwa 19 July 2017, Saya Tamura 992 $, 993^{\dagger}, 994^{\dagger}, 995^{\dagger}$ (SAPT).

S. rebunshirensis: RUSSIA. Sakhalin: S. Saghallen Mt. Tosso, 23 July 1927, Hiratsuka N., Nagai M. \& Iwadare S. s.n. ${ }^{\mathrm{A}}$ * (SAPS). Mt. Tosso, July 1927, Sugawara s.n. ${ }^{\mathrm{A}}$ (TNS). Kusu river, 18 July 1928, Okamae Tsutomu $252162^{\mathrm{F}}$ (TNS). Shirutoru,13 July 1929, Haga T. 13939A (SAPS). Mt. Tosso, 13 July 1929, Haga T. $13936^{\mathrm{A}}$ (SAPS). Shirutoru, 14 July 1929, Haga T. 13937 (SAPS). Mt. Tosso, July 1929, 20855 (TNS). Kasipo, 1 August 1929, 21329**(TNS). Sakhalin, July 1930, Shigezou Sugawara 12105 ${ }^{\mathrm{*} *}$ (SAPT). Shirutori Mt. Ishiyama, 20 July 1935, Shigezou Sugawara 12106 ${ }^{\mathrm{C}}$ (SAPT). Hoe, 23 August 1935, Nakaji Masayoshi s.n. ${ }^{\mathrm{A}}$ (TNS). South of the Peninsula of Schmidt, 16 August 2001, Fukuda T. 2211 E* (SAPS). Peninsula of Schmidt, 14 August 2001, Barkarov V. Y. 10812 ${ }^{\mathrm{D} *}$ (SAPS). Eastern coast of the Peninsula of Schmidt, 14 August 2001, Fukuda T. 2117 ${ }^{\mathrm{E}}$ (SAPS). South of the Peninsula of Schmidt, 16 August 2001, Fukuda T. 2198 ${ }^{\mathrm{E}}, 2211^{\mathrm{E}}$ (SAPS). Tikhaya village, 28 August 2001, Fukuda T. $2483^{\mathrm{E}}$ (SAPS). Mt. Zhdanko, 2 August 2002, Hideki Takahashi $30172^{\mathrm{C}}$ (SAPS). Mt. Ostrovskaya, 3 August 2002, Noriyuki Fujii $01133^{\mathrm{C}}$ (SAPS). Mt. Changa, 7 August 2002, Hideki Takahashi 30264C , 30309' (SAPS). Central Sakhalin Mt. Chamga, 17 August 2006, Ken Sato, 06.0201 (SAPS). Central Sakhalin Mt. Vaida, 20 August 2006, Ken Sato 06.0316 (SAPS). Mt. Calcareous, 11 July 2007, Takahashi H., Kawahara T., Kitamura K. \& Taran A., 33.763 ${ }^{\mathrm{E}}$ (SAPS). RUSSIA. Kuril Islands: Shikotan, 3 July 1930, Tôno S. s.n. ${ }^{\mathrm{C}}$ (SAPT). JAPAN. Hokkaido: Mt. Rishiri, 6 July 1914, s.n. ${ }^{\mathrm{A}}$ (TNS). Rebun Island, 10 July 1914, Tamaki Seiichi 26106 ${ }^{\mathrm{F}}$ (TNS). Mt. Ashibetsu Ishikari, 30 July 1915, Koidzumi Hideo $67488^{\mathrm{A}}$ (TNS). Kamifurano, 8 September 1915, Koidzumi Hideo 74161 ${ }^{\mathrm{F} *}, 74162^{\mathrm{F}}$ (TNS). Mt. Kamifurano, 13 July 1917, Koidzumi Hideo $76906^{\mathrm{F}}$ (TNS). Mt. Rishiri, 5 August 1922, Hiratsuka Naohide s.n. ${ }^{A}$ (TNS). Kamikawamura, 24-27 August 1926, Koidzumi Hideo $13157^{\mathrm{F}}$ (TNS). Mt. Chubetsuhondake, 19 August 1927, Koidzumi Hideo 15046 ${ }^{\mathrm{F}}$ (TNS). Mt. Nipesotsu, 25-26 August 1927, Koidzumi Hideo 15339F (TNS). Mt. Yubari, 25 July 1928, Koidzumi Hideo 63705F (TNS). Mt. Rishiri, 23 July 1929, Shigeo Akiyama s.n. ${ }^{\mathrm{A}}$ (SAPS). Mt. Rishiri, July 1929, Akiyama S. s.n. ${ }^{\mathrm{A}}$ (SAPS). Shakotan, 3 July 1930, Tôno S. $010397^{\mathrm{C}}$ (SAPT). Mt. Rishiri, 13 August 1952, Furuse Miyoshi 130160F (TNS). Mt. Jozankei-Tengu, 3 July 1955, Toyokuni H. s.n. ${ }^{\mathrm{C}}$ (SAPS). Mt. Rishiri, 29 July 1956, Haginiwa Joju JH046164C (TNS). Mt. Taisetsu, 11 August 1956, Toyokuni H. 027749 (SAPS). Mt. Rishiri, 3 August 1957, Satake Yoshisuke \& Ito Eiko 266166, $273271^{\mathrm{F}}$ (TNS). Mt. Shari, 31 July 1959, Kawashiro Z. s.n. ${ }^{\mathrm{B}}$ (SAPS). Mt. Rausu Shiretoko, 11 July 1965, Haga S.\& Saitou R. $308044^{\mathrm{B}}$ (TNS). Mt. Rishiri, 13 August 1965, 498 (TNS). Mt. Rhishiri, 13 August 1965, Andoh Yukio 347 (TNS). Mt. Rhishiri, 13 August 1965, Harajima Hisao 889 ${ }^{\mathrm{F}}$ (TNS). Mt. Rishiri, 13 August 1965, Masuda Shinya 487 498 $^{\mathrm{F}}, 711^{\mathrm{B} *}$ (TNS). Mt. Zyozankeitengu,15 June 1969, Ken Sato 69.0101 ${ }^{\mathrm{B}}$ (SAPS). Mt. Zyozankei-Tengu, 18 June 1970, Ken Sato $70.2802^{\mathrm{F}}$, $70.2801^{\mathrm{F}}$ (SAPS). Mt.Zyozankei-Tengu, 24 June 1970, Watanabe $S . \mathrm{W} 153^{\mathrm{F}}, 154^{\mathrm{F}}, 155^{\mathrm{F}}, 156^{\mathrm{F}}$ (SAPS). Mt. Rausu, 6 July 1970, Togashi M. $273107^{\mathrm{F}}$ (TNS). Mt. Rausu, 9 september 1971, Sato K. \& Nishikawa T. 71.5062 (SAPS). Mt. Yûpari at Rôsoku-iwa, 6 August 1973, Shiro Nosaka 031581 C*, 031582 C* (SAPS). Mt. Rausu, 14 August 1979, Sato

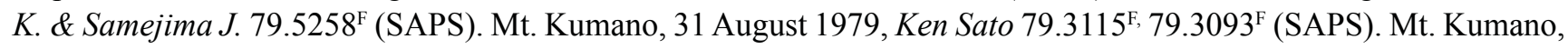
17 July 1981, Ken Sato 81.0135 $5^{\mathrm{F}}$, 81.0136 (SAPS). Pankechiebu, 24 June 1982, Ken Sato 82.0517 ${ }^{\mathrm{F}}, 82.0516^{\mathrm{F}}$ (SAPS).

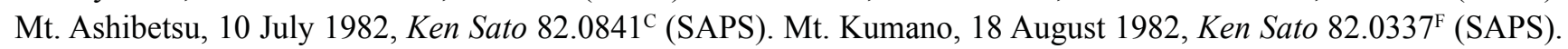
Rebun Island, 13 July 1983, Ken Sato 83.0202 (SAPS). Mt. Kumano, 2 August 1983, Tsuchida T. 010396 (SAPT). Mt. Yubari Rosoku-iwa, 22 August 1985, Ken Sato 85.0207 (SAPS). Hoheikyo, 11 July 1986, Matsuji Hara 6470 ${ }^{\mathrm{C}}$ (SAPS). Mt. Nishi-kumaneshiri-dake, 12 August 1987, Takahashi H., Kawabata K., Kushibiki E., Kikuzawa Y.\& Kudo T. $7872^{\mathrm{C}}, 7885^{\mathrm{C}}$ (SAPS). Mt. Tengu-dake, 24 July 1988, Takahashi H., Hara M., Sato K. \& Umezawa S. 8548C (SAPS). Mt. Rausu, 7 July 1991, Takita K. 4766 ${ }^{\mathrm{B}}$ (SAPT). Mt. Nipesotsu, 4 August 1991, Takita K. 5076 ${ }^{\mathrm{B} *}$ (SAPT). Kamishihoro town Mt. Nishi-kumaneshiri, 27 July 1994, Ken Sato 94.0786, 94.0834 (SAPS). Mt. Rishiri Kutsugata-peak, 11 August 1994, Ken Sato 94.0990 (SAPS). Rebun Island Momo-iwa, 10 June 2016, Saya Tamura 328 , 329†(SAPT). Mt. NishiKumaneshiri cultivated in the Botanic Garden, Hokkaido University, 1 July 2016, Saya Tamura $434^{\dagger}, 436^{\dagger}$ (SAPT). JAPAN.Honshu: Mt. Shirouma, 26 August 1902, Yabe Yoshisada 24445 (TNS). Mt. Yatsugadake Koshu, 30 August

68 - Phytotaxa 373 (1) C 2018 Magnolia Press

TAMURA ET AL. 
1902, Hayata B. $18763^{\mathrm{A}}$ (SAPS). Mt. Yatsugadake Shinshu, August 1902, Hayata B. 18761, 18762, 18764F (SAPS). Mt. Amida, 25 July 1903, Takeda H. s.n. ${ }^{\mathrm{A}}$ (SAPS). Mt. Togakushiura, 19 July 1904, Takeda H. s.n. ${ }^{\mathrm{A}}$ (SAPS). Mt. Yatsugadake Shinshu, 21 July 1904, Takeda H. s.n. ${ }^{\mathrm{A}}$ (SAPS). Mt. Shirouma Shinshu, 16 August 1905, Takeda F. s.n. ${ }^{\mathrm{A}}$ (TNS). Mt. Shirouma Shinshu, 11 August 1906, Miura Michiya s.n. ${ }^{\mathrm{A}}$ (TNS). Mt. Yatsugatake, August 1906, Sakurai Hanzaburo $6635^{\mathrm{F}}$ (TNS). Mt. Yatsugatake Shinano, 26 July 1908, Iishiba Eikichi s.n. ${ }^{\mathrm{C}}$ (TNS). Mt. Ohrenge Echigo, 10 August 1908, Nakamura Masao 94366 F* (TNS). Mt. Shirouma Shinano, 15-16 August 1908, Shimura H. $138822^{\mathrm{F}}$ (TNS). Mt. Yatsugatake Shinshu, 13 August 1910, Koidzumi Hideo 67489 (TNS). Mt. Hariki Shinano, 25 July 1913, Yamakawa S. 264 (TNS). Mt. Shirouma, 4 August 1913, Yazawa Yonesaburo s.n. ${ }^{\text {A* }}$ (TNS). Mt. Senjo Nagano, 9 August 1913, Takeda H. 3663 (TNS). Mt. Senjogatake Shinshu, 10 August 1916, Koidzumi Hideo 67492 ${ }^{\mathrm{A}}$ (TNS). Mt. Yatsugatake Shinshu, August 1916, Koidzumi Hideo 67491 ${ }^{\mathrm{F}}$ (TNS). Mt. Hotaka Hida, 1 September 1916, Koidzumi Hideo $26206^{\mathrm{F}}$ (TNS). Mt. Shirouma Shinano, 27 July 1917, Matsushima M. 37204 (TNS). Mt. Shirouma, 28 July 1920, Yazawa Yonesaburo s.n. ${ }^{\mathrm{A}}$ (TNS). Mt. Shirouma Shinano, 26-30 August 1920, Koidzumi Hideo $785^{\mathrm{F}}$ (TNS). Mt. Shirouma Shinano, 21 July 1921, Koidzumi Hideo 45051 $1^{\mathrm{F}}$ (TNS). Mt. Kaisuruga Shinano, 27 July 1921, Koidzumi Hideo $2035^{\mathrm{F}}$ (TNS). Mt. Tsuba-Kuro Shinano, 22 July 1921, Koidzumi Hideo 1909 ${ }^{\mathrm{F}}$, 67367 (TNS). Mt. Senjo Shinano, 25 July 1922, Koidzumi Hideo 3516 (TNS). Mt. Senjo Shinano, 26 July 1922, Koidzumi Hideo $73067^{\mathrm{F}}$ (TNS). Mt. Shiomi Shinano, 28 July 1922, Koidzumi Hideo 3652 $2^{\mathrm{F}}$ (TNS). Mt. Kogoochi Shinano, 29 July 1922, Koidzumi Hideo $3717^{\mathrm{F}}$ (TNS). Shimoina Shinano, 30 July 1922, Koidzumi Hideo 3725 ${ }^{\mathrm{F}}$ (TNS). Mt. Arakawadake Shinshu, 31 July 1922, Koidzumi Hideo 67490 ${ }^{\mathrm{F}}$ (TNS). Mt. Kitadake Koshu, 7 August 1922, Koidzumi Hideo 3882 ${ }^{\mathrm{F}}$ (TNS). Mt. Yatsugadake Shinano, 28 August 1922, Koidzumi Hideo 4486 ${ }^{\mathrm{F}}$ (TNS). Mt. Nokogiri Shinano, 29 July 1923, Koidzumi Hideo 5309 (TNS). Mt. Yatsugatake Nagano, 29 July 1923, Koidzumi Hideo 91244 (TNS). Mt. Arakawa Shinshu, 31 July 1923, Koidzumi Hideo 67494A (TNS). Kitaadzumigun Shinano, 6 August 1923, Koidzumi Hideo 48821F (TNS). Mt. Daitenjo Shinano, 6 August 1923, Koidzumi Hideo 64254F (TNS). Mt. Yari Shinano, 7 August 1923, Koidzumi Hideo $5087^{\mathrm{F}}, 64257^{\mathrm{F}}$ (TNS). Mt. Kitahotaka Shinano, 7 August 1923, Koidzumi Hideo $48387^{\mathrm{F}}$ (TNS). Mt. Ohtenjo Shinano, 8 August 1923, Koidzumi Hideo 48274 (TNS). Mt. Harinoki Shinano, 18 August 1923, Koidzumi Hideo $5734^{\mathrm{F}}$ (TNS). Mt. Yari Hida, 24 August 1923, Koidzumi Hideo 5954 ${ }^{\mathrm{F}}$ (TNS). Mt. Yatsugatake Gongendake Shinano, 30 August 1923, Koidzumi Hideo 6005 (TNS). Mt. Ushikubi Shinano, August 1923, Koidzumi Hideo 5043 ${ }^{\mathrm{F}}$ (TNS). Mt. Kurodake Kamishinkawagun, 1923, Koidzumi Hideo 5859F (TNS). Mt. Maekogouchidake Shinano, 1923, Koidzumi Hideo 44023 ${ }^{\mathrm{F}}$ (TNS). Mt. Tsugamura Suruga, 22 July 1924, Koidzumi Hideo 496871 ${ }^{\mathrm{F}}$ (TNS). Mt. Shiomi, July 1924,

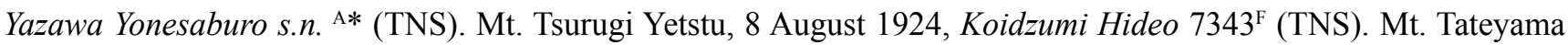
Yetstu, 9 August 1924, Koidzumi Hideo 7890 ${ }^{\mathrm{F}}$ (TNS). Mt. Akaishi range Kai-Suruga, 2-9 July 1925, Koidzumi Hideo 9562 $2^{\mathrm{F}}, 61484^{\mathrm{F}}, 51496^{\mathrm{F}}$ (TNS). Mt. Shirouma Shinano, July 1925, Koidzumi Hideo $10929^{\mathrm{F}}$ (TNS). Mt. Akaishi range, 8 August 1925, Koidzumi Hideo 9563 (TNS). Mt. Senjo Kai, 29 August 1925, Ohwi Jizaburo 224189 (TNS). Mt. Tateyama Yetsiu, July 1926, Koidzumi Hideo, $12136^{\mathrm{F}}$ (TNS). Mt. Yatsugatake, 18 July 1927, s.n. ${ }^{\mathrm{A}}$ (TNS). Mt. Yatsugatake Shinano, 7 July 1928, Koidzumi Hideo $88652^{\mathrm{F}}$ (TNS). Mt. Yatsugadake Shinshu, 28 July 1928, Inagaki K. s.n. ${ }^{\mathrm{A}}$ (SAPS). Mt. Kisokoma Shinano, 4 August 1928, Koidzumi Hideo $1044^{\mathrm{F}}$ (TNS). Mt. Hotaka Shinano, 2 September 1929, Koidzumi Hideo 19029 $, 19030^{\mathrm{F}}, 19032^{\mathrm{F} *}, 55500^{\mathrm{F}}$ (TNS). Mt. Norikura Shinano, 27 July 1930, Koidzumi Hideo \& Yokouchi I. 87496 ${ }^{\mathrm{F}}$ (TNS). Mt. Ioh Nagano, July 1930, Maekawa Fumio 85567 (TNS). Mt. Shiomi Shinano, 3 August 1930, Muramatsu Kouki 3453 (TNS). Mt. Kanenashi Shinano, 23 July 1931, Koidzumi Hideo 45346F (TNS). Mt. Arakawa Suruga, 7 August 1931, Hashimoto $44088^{\mathrm{F}}$ (TNS). Mt. Akaishi Suruga, 8 August 1931, Suzuki S. s.n. ${ }^{\mathrm{A}}$ (TNS). Sannomine Echizen, 22 July 1933, Tashiro Yoshitaro 42366 ${ }^{\mathrm{F}}$ (TNS). Mt. Kisokoma, 22 August 1934, Koidzumi

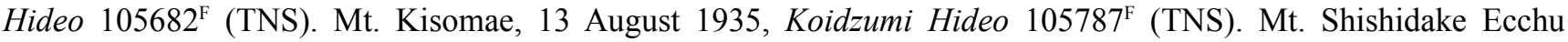
Tateyama, 28 July 1937, s.n. ${ }^{\text {C }(T N S) . ~ M t . ~ S e n j o ~ K a i, ~} 1$ August 1938, Okuyama Shunki 4192 ${ }^{C}$ (TNS). Mt. Shimizu Etchu, 2 August 1938, Hayashi, 69396 ${ }^{\mathrm{F}}$ (TNS). Mt. Higashi Suruga, 1 August 1948, Hirano Hideo. $79776^{\mathrm{F}}$ (TNS). Mt. Yatsugatake Shinano-Kai, 27 July 1949, Haginiwa Joju JH009022C ${ }^{C}$, JH009023C , JH046160 (TNS). Mt. Higashi Suruga, 2 August 1949, Hirano Hideo. 32 ${ }^{\mathrm{F}}$ (TNS). Mt. Kamikouchi Shinano, 26 July 1951, Muramatsu Kouki 3052 ${ }^{\mathrm{F}}$ (TNS). Mt. Higashi Shinano, 29 July 1951, Muramatsu Kouki 3324 (TNS). Mt. Senjo, August 1952, Iwatsuki Z. s.n. ${ }^{\mathrm{F}}$ (TNS). Mt. Yatsugatake Shinano, 12 July 1953, Haginiwa Joju JH046163 (TNS). Mt. Yatsugatake Shinano, 28 July 1953, Ueda Minoru 104289 (TNS). Mt. Akusawa Suruga, 23 August 1953, Haginiwa Joju JH009021 ${ }^{\mathrm{A}}$ (TNS). Kisawa village, 3 August 1956, Muramatsu Kouki 2603ㄹ (TNS). Yamadera-oku Yamagata, 10 June 1957, Kato Nobuo $133441^{\mathrm{C}}$ (TNS). Mt. Akaishi Shinano, 4 August 1958, Ibaragi Yoichi 139447C (TNS). Mt. Harinoki Shinano, 30 July 1959, Okuyama Shunki \& Utsumi H. $15618^{\mathrm{C}}$ (TNS). Mt. Harinoki Shinano, 30 July 1959, Okuyama Shunki $15675^{\mathrm{F}}$ (TNS). Sanpusi-touge Nagano, 4 August 1962, Kogure Kazuo 152954 ${ }^{\text {B }}$ (TNS). Mt. Kitadake Yamanashi, 21 August 1962, Ishizawa $8240^{\mathrm{F}}$ (TNS). Mt. Kitadake Kai, 6 August 1963, Nakamura Takehisa 594C (TNS). Mt. Kitadake Kai, 7 August 1963, Ohtake Iwao 387, 388 (TNS). Mt. Kitadake Kai, 7 August 1963, Masuda Shinya 2395, 2424, 2455, 2530 
(TNS). Mt. Higashi-Arakawa Shizuoka, 1 September 1963, Iwatsuki K.\& Koyama K. 153E (TNS). Mt. Kogouchi Shinano, 16 August 1964, Masuda Shinya 3435 (TNS). Otomiyama-touge Echigo, 3 August 1965, Okuyama Shunki $24735^{\mathrm{C}}$ (TNS). Mt. Senjo Shinano, 20 August 1966, Masuda Shinya 5289 (TNS). Mt. Shiomi to Mt. Kita-arakawa in Minami Alps National Park, 1 August 1967, Konta F. \& Takahashi H. 511 ${ }^{\text {B }}$ (TNS). Mt. Yatsu Shinano, 20 August 1968, Okuyama Shunki 12444C (TNS). Asahigoya-Mt. Yukikura Toyama, 29 August 1969, Satomi N.\& Mochizuki R. 256064C (TNS). Sanpukutouge-Eboshi Nagano, 7 July 1971, Kojima Yu 340 (TNS). Mt. Amakazari, 29 July 1975, Nomura Kouhei 39383 ${ }^{\mathrm{B}}$ (TNS). Mt. Amakazari Niigata, 14 August 1978, Sakuma Yoshihisa s.n. ${ }^{\mathrm{F}}$ (TNS). Mt. Amakazari Niigata, 12 August 1980, Sakuma Yoshihisa s.n. ${ }^{\mathrm{F}}$ (TNS). Mt. Tsurugi Toyama, 1 September 1980, Takai Yumi 949 (TNS). Mt. Senmai South alps, 31 August 1984, Konta Fumihiro. 15688 ${ }^{\mathrm{B}}$ (TNS). Mt. Hakuba cultivated at Hakuba Goryu Alpine Botanical Garden, 16 June 2016, Saya Tamura 334† 335 (SAPT). Mt. Kamikouchi Suruga, Koidzumi Hideo $6882^{\mathrm{F}}$ (TNS). Mt. Kitahotaka Shinshu, Koidzumi Hideo 67470

S. nishidae: JAPAN. Hokkaido: Holotype (designated by Miyabe \& Kudo 1917)—Mt. Yubari at Gamaiwa, 7 August 1916, Shozo Nishida 037669 (SAPS!). Mt. Yubari, 3 August 1921, Takeda \& Tatewaki 016363, 016364, 016365 (SAPS). Mt. Yubari Gamaiwa, 22-26 July 1928, Koidzumi Hideo 16912, 16913 (TNS). Mt. Yubari, 24 July 1928, Koidzumi Hideo 16911 (TNS). Mt. Yubari, 1 August 1933, Sugimoto Junichi 45613 (TNS). Mt. Yupari Gama-iwa, 18 August 1957, Shiro Nosaka 031624 (SAPS). Mt. Yubari, 1 August 1987, Hideki Takahashi 016362 (SAPS). Mt. Yubari, 6 August 1991, Ken Sato 91.1327, 91.1707 (SAPS). Mt. Yubari, 22 July 1995, Takita K. 6312 (SAPT). Mt. Yubari, 3 August 2014, Ken Sato 14.200 (SAPS). Mt. Ashibetsu meotoiwa, 22 July 2014, Nakagawa 14019, 14020 (SAPS). Mt. Yubari Gama-iwa, 26 July 2016, Saya Tamura 589, 594, 610, 615, 620, 627 (SAPT). Mt. Yubari Gamaiwa 19 July 2017, Saya Tamura 996 ${ }^{\dagger}, 997^{\dagger}, 998^{\dagger}, 999^{\dagger}$ (SAPT).

A, Saxifraga bronchialis L.; B, Saxifraga bronchialis L. subsp. funstonii (Small) Hulten var. rebunshirensis Hara; C, Saxifraga cherlerioides D.Don var. rebunshirensis Hara; D, Saxifraga rebunshirensis (Engl. Et Irmsh.) Sipl.; E, Saxifraga sp.; F, Shikotanso (Japanese name) 